\title{
Legal means of supporting the agro-industrial complex of the Russian Federation
}

\author{
Anastasia Chertova ${ }^{1, *}$ \\ ${ }^{1}$ Institute of Service Sector and Entrepreneurship (Branch) of the Don State Technical University in \\ Shakhty, Shevchenko 147, Shakhty city, Rostov region, 346500, Russia
}

\begin{abstract}
This article analyses modern state agrarian policy, which focuses on a wide range of issues of socio-economic development of rural territories. Statistics show that the agro-industrial complex is currently showing promising and qualitative development, including providing the country with the main groups of food products. However, despite certain changes in production, the expansion of state support measures in the agro-industrial complex remains a number of significant issues that need to be resolved in a timely manner
\end{abstract}

\section{Introduction}

The agro-industrial complex of Russia is a recognized sector of the economy, whose products are constantly in demand. State support for agriculture is an important element in the regulation of the agro-industrial complex. The economic efficiency of agricultural production, the condition of rural areas, its level of development and the degree of quality of food security will completely depend on its effective use. The effectiveness of the mechanism of state support for the agro-industrial complex is primarily necessary for the implementation of the import substitution program and ensuring the country's food security.

In the Russian Federation, State support has recently become the main base of agrarian policy. At the same time, state authorities at the same time, when managing the free market, which forms competitive relations in the agricultural sector and related industries, implement active state regulation of this industry. It should be noted that the agro-industrial complex, when operating in crisis conditions, is exposed to an increased degree of production, financial and political risks, which in turn determines the improvement of state policy in the agrarian sphere and mechanisms of state support and state regulation of this sector.

The State policy of the Russian Federation reflects the full essence and nature of the State; it is designed to create conditions in the life of society for improving management mechanisms, to introduce rationalization and innovation ideas, plans and proposals, with the help of which the strengthening and systematization of the foundations of the development of the individual and the State will be implemented. Among the wide variety of forms and types, State policy attaches particular importance to agrarian policy, which is implemented in the development of agriculture, the agro-industrial complex, the effective use of

* Corresponding author: chertova-osipchuk@mail.ru 
agricultural technologies, ensuring food security, improving technologies and the organizational and legal situation of domestic agricultural production and trade.

The main goal of the study is to study the main trends in the development of state support for the agro-industrial complex of the Russian Federation, identify its problematic aspects and determine the main directions for its improvement.

\section{Methodology}

Through statistical methods, comparison methods in economic and legal analysis, the possibilities of the main trends in the development of state support for the agro-industrial complex of the Russian Federation are studied

\section{Results of the research}

Modern state agrarian policy is aimed at solving issues of socio-economic and legal development of rural territories. Today, about 37 million people live in the Russian countryside, which is almost a quarter of the country's population. This circumstance updates the state agrarian policy of the country.

The most important aspect in this regard is the integration of the content and dynamics of legal means in the mechanism of legal regulation of agrarian legal relations. State agrarian policy is a system of complex, interconnected principles, methods, forms of activity of state and municipal agrarian business management bodies related to the formation of legal means, their strategic implementation, taking into account the natural and territorial potential of the country and aimed at the systematic and effective development of agriculture and the agroindustrial complex of the Russian Federation.

Main areas: the development of preferential leasing, which will be used to update equipment and equipment; building a system according to which from 2020 state support to the constituent entities of the Russian Federation will be carried out within the framework of certain compensating subsidies; Identification of relevant groups of enterprises and research institutions that, in turn, are comprehensively capable of implementing advanced technologies and national agricultural resources; Within the framework of the implementation of agrarian legal policy, it is necessary to highlight the main areas of improvement of the agrarian education system: increasing the volume of practical part in agrarian training, improving the quality of educational and production practices, ensuring partnership unions between local governments of rural entities, agricultural producers and higher educational institutions of the agrarian direction; The management and support of agricultural actors should be improved and centralized; To pay attention to the comprehensive provision of guarantees of stability and effective functioning of state regulation, which will make it possible to achieve a positive reduction in energy costs for small and medium-sized enterprises of the agro-industrial complex; for the subjects of the Russian Federation to establish the right to fix to small agricultural producers a minimum part of the sale of their products, it is recommended to add this supplement to the Federal Law "On the Basics of State Regulation of Trade Activities in the Russian Federation"; Provide an opportunity to establish a mechanism for wholesale food markets that have high demand in many countries; development of online trade in raw materials and foodstuffs produced in rural areas, by involving the banking unit in large-scale work to finance the main agricultural industries and by systematically developing small businesses in rural areas by expanding work tools; compensations transport costs to organizations and entrepreneurs engaged in trade activities in remote and small rural areas; reduction of tax burden; provide an opportunity to participate in grants for the formation of non-agricultural business; 
subsidize the initial contribution for housing in rural areas from the budget of a certain region, the introduction of a preferential rate within 5 percent would solve the existing problem; it is necessary to provide for "Integration of rural development" as part of the state program, which will allow providing subsidies from the federal budget to the budgets of the constituent entities of the Russian Federation.

The application of the above-mentioned measures of state support will improve the modern agrarian policy, as well as the tools for its implementation within the framework of the State Program for the Development of Agriculture and the Regulation of Markets for Agricultural Products, Raw Materials and Food.

\section{Discussion of results}

State agrarian policy must be considered in two aspects at once, namely, economic and legal. In economic terms, agrarian policy is a certain functioning system of concrete goals and measures that are related to the creation of financial and economic conditions under which the agrarian sector of the economy is ensured, as well as the complex mechanisms of agriculture and foreign trade cooperation. In the legal aspect, agrarian policy is a joint activity of the state and municipal authorities, civil society institutions aimed at creating, improving and systematizing agricultural products and raw materials, as well as maintaining a domestic producer [1].

Legal science pays special attention to the legal regulation of the agro-industrial complex, which once again proves the fact that this area of regulation is promising [2]. State agrarian policy is seen as a link between the systemic development of the agricultural sector of the economy, trends in technological opportunities in agricultural production, the application of modern methods and forms of development, strengthening and improving the quality of agricultural modernization as the main indicator of the national macroeconomic system.

In legal science, State agrarian policy is identified as a multifaceted part of State social and economic policy, the purpose of which is to guide the highly stable development of agriculture and rural areas. Among other things, sustainable rural development refers to sustainable socio-economic functioning, as well as increased agricultural production, improved agricultural efficiency, the positive result of full employment of the rural population and improvement of its quality of life, rational and functional use of land. In this aspect of the State agrarian policy, the fundamental center is a set of legal measures aimed at the effective implementation of the goals and objectives of State activity in the field of agricultural production [3]. These legal means of State agrarian policy are legal phenomena, which are expressed in the form of legal instruments and acts aimed at achieving general and certain tasks in the field of agriculture and the agro-industrial complex of Russia.

Today, in the Russian Federation, agrarian policy is fully based on market mechanisms, the full use of innovations and technologies, the predictability of the forms and methods on which economic activities in the agrarian sector of the economy are based, which originates from state-owned enterprises and stops at the cooperative and farm activities of certain owners. Based on these circumstances, we note that it is necessary to recognize the difficulty of the content of the state agrarian policy, the emergence and collection of principles and directions in its construction, legal means and organizational methods for achieving significant results [4].

In the theory of law, legal means are described in general terms as simple, combined, as well as complex. Note that they differ in their content, purpose and place in the legal regulation mechanism.

Simple legal means are rules of law that establish subjective rights, legal obligations, prohibitions, restrictions, including legitimate interests, rights and guarantees of the activities of participants in agrarian legal relations. These legal relations arise during the production, 
sale, lease, distribution of agricultural products, material, as well as production funds and working resources. Agrarian legal relations also form civil law, land, administrative, municipal, investment norms [5].

Combined legal means cover the entire system of legal means, their configuration, have a direct direction of implementation in the field of state agrarian leadership. These legal means are legal regimes, legal responsibility, legal incentives, legal statuses, legal practice. They ensure the formation of a systematic, effective and profitable economic and political system of the legal status of modern agricultural producers, including their unions, associations, state and municipal authorities [6].

Complex legal means in the legal literature are a complete set of mechanisms for legal influence on the sphere of public relations, the formation of a systemic and positive legal result in the relevant sphere.

In this study, we will highlight the following complex legal means: law-making, legal interpretation, legal implementation and law enforcement:

1. Law-making is a certain procedural activity of authorized structures, through which relevant normative legal acts and sources of law are established and implemented. To date, such regulatory legal acts as the Federal Law of December 29, 2006 «On the Development of Agriculture» and the Federal Scientific and Technical Program for the Development of Agriculture for 2017-2025, approved by the Government of the Russian Federation, have been adopted and are in force. The law-making work of the Government of Russia to prolong the State Program for the Development of Agriculture and Regulation of Agricultural Products, Food and Raw Materials Markets, and the formation of an effective strategy until 2030 are also relevant.

It should also be noted that regulatory decisions are systematically made at the level of ministries, for example, the order of the Ministry of Agriculture of the Russian Federation «On approval of the procedure for managing the implementation of the state program for the development of agriculture and the regulation of markets for agricultural products, raw materials and food» dated February 6, 2020. In this case, there is an interdepartmental unified mechanism of law-making, ensuring the full implementation of the goals and objectives of the full development of agriculture, while regulating positive indicators of results and achievements in certain sectors of agriculture [7].

2. Legal interpretation is a complex legal tool and in the implementation of state agrarian policy today occupies a special promising character. First of all, this can be explained by the fact that the necessary scope of regulatory provisions is being formed and systematized, which establish the basic and special principles, conditions and directions for the integrated development of agriculture and related sectors of our country's economy. Second, it is necessary to draw attention to certain decisions of the highest courts, which are taken in order to formally interpret certain legislative acts [8].

3. Legal implementation in the process of which the rights and obligations of entrepreneurial structures, agricultural producers, unions and associations of Russian agricultural workers are realized. Within the framework of State agrarian policy, the complex legal instrument under consideration demonstrates its practical effect within the specified areas [9].

These areas should include the following:

- Work on updating the material and technical base of rural areas. A positive aspect of this direction is now that on the one hand, agricultural enterprises are becoming active consumers of modern technologies, and on the other hand, agricultural enterprises are purchasing new equipment and equipment to simplify and improve work, and are introducing effective technologies that will increase the volume and quality of agricultural products. In the modernization of the agro-industrial complex, state assistance is needed. The most important support is: the development of preferential leasing, which will be used to update 
equipment and equipment; building a system according to which from 2020 state support to the constituent entities of the Russian Federation will be carried out within the framework of certain compensating subsidies. These subsidies are aimed at supporting agricultural production in certain sectors of seed production and farming; regulation of rules for subsidizing transport costs for finished products of the agro-industrial complex; by 2022, agricultural producers will have the opportunity to independently register a complete set of state support measures on the public services portal, we believe that this opportunity will simplify the receipt of support from the state and reduce the corruption focus in this area.

- Agrarian business. Agrarian business promotes the use by legal entities of a complete set of legal instruments that are necessary for the development of public, private and mixed forms of economic activity in the agrarian sphere. It is necessary to identify a group of enterprises and research institutions that, in turn, are comprehensively capable of implementing advanced technologies and national agricultural resources in practice. From this, the idea of a systematic study of factors, order, conditions for agricultural activities by Russian citizens should be supported [10]. The primary role in this issue is played by the priority guidelines and life values of modern youth, graduates of agrarian universities, young residents of rural areas as potential agricultural workers [11].

- Higher education. In recent years, the situation with graduates of agricultural universities who want to work in the agricultural sector has been changing for the better. The developed legal and social thinking of students ensures the perspective and importance of the realization of their knowledge and the desire for the development of agriculture. It should be noted that the priority task of agrarian education is not only the allocation of certain groups wishing to work in rural areas, but also comprehensive assistance to them in terms of training and stimulation [12]. According to data, today there are 54 agricultural universities in the country, in which about 310 thousand people study. In 20 universities of the system of the Ministry of Science and Higher Education there are agricultural faculties. Also, 253 technical schools and colleges are included in the agricultural education system. Turning to the data of the Ministry of Agriculture of Russia, we come to the conclusion that more than 90 percent of graduates of agricultural universities do not work in their specialties. In this regard, it is necessary to recognize the introduction of a new range of specialties that would allow students to choose in the direction of mastering new technologies, which, for example, could be related to the greening, digitalization and robotics of agriculture. Within the framework of the implementation of agrarian legal policy, it is necessary to highlight the main directions for improving the system of agrarian education: an increase in the volume of practical part in agrarian education; improving the quality of training and production practices; provision of partnership unions between local self-government bodies of rural entities, agricultural producers and higher educational institutions of the agrarian direction.

- Quality industry and research base. Currently, the Federal Scientific and Technical Program for the Development of Agriculture has been implemented in Russia since 2017. In this regard, first of all, due to the rather strong dependence on foreign tribal and sown material, issues of the development of domestic breeding and genetics need to be resolved. Currently, four institutions subordinate to the Ministry of Agriculture, including 54 organizations that are part of the Ministry of Higher Education and Science, are implementing research activities in the field of genetics and seed production. We believe it is necessary to improve and centralize the management and support of entities working in this field. Secondly, we should pay attention to the comprehensive provision of guarantees for the stability and effective functioning of state regulation, which will make it possible to achieve a positive reduction in energy costs for small and medium-sized enterprises of the agroindustrial complex [13]. They also pay special attention to proposals that explore the socioeconomic development of the country as the most important priority of the Russian Federation. Issues related to innovative and technological support for agriculture, the 
preservation and development of the personnel potential of the scientific and technical complex, the development of international cooperation, and countering crime in the agroindustrial complex and rural areas should not be isolated.

- Quantitative growth of medium and small producers in trade networks. We believe that in order to resolve this area, it is necessary to continue the functioning of organized forms of trade, since in 2010 retail markets and fairs accounted for a total of more than 12 percent of the total trade turnover, but then there was a process of their reduction, in January 2020 the share of retail markets and fairs amounted to 5.3 percent (in January 2019, the share of retail markets and fairs was 5.6 percent).

Next, the problem of affordable marketing of agricultural products should be considered. Today, agricultural producers are faced with the choice to sell their products to resellers or sell at a lower cost. Retail chains rarely provide places for the products of producers of rural areas. Note that as of January 1, 2020, 242 agricultural and agricultural cooperative markets functioned, of these, about 149 markets were located in capital buildings and structures, or 61.6 percent of the total, but the level of actual use of trading places in the markets as of January 1, 2020 on average for the Russian Federation was 64,2 percent, which is lower than on the same date in 2019 (See Table 1. Level of actual usage of trading places).

Table 1. Level of actual usage of trading places.

\begin{tabular}{|c|c|c|c|c|c|}
\hline & \multicolumn{4}{|c|}{2019} & \multirow{2}{*}{$\begin{array}{c}\text { As of } \\
\text { January } \\
1.2020 .\end{array}$} \\
\hline & $\begin{array}{c}\text { on } 1 \\
\text { January }\end{array}$ & $\begin{array}{c}\text { as of } \\
\text { April } 1\end{array}$ & $\begin{array}{c}\text { as of } \\
\text { July } 1\end{array}$ & $\begin{array}{c}\text { on } 1 \\
\text { October }\end{array}$ & \\
\hline Markets & 66.7 & 65.1 & 66.1 & 66.0 & 64.2 \\
\hline universal markets & 69.1 & 67.8 & 68.4 & 68.1 & 66.2 \\
\hline specialized food markets & 59.4 & 57.9 & 62.8 & 60.0 & 58.6 \\
\hline $\begin{array}{ll}\text { Specialized } & \text { substance } \\
\text { markets } & \end{array}$ & 69.9 & 63.2 & 61.4 & 64.8 & 62.7 \\
\hline $\begin{array}{l}\text { specialized markets for the } \\
\text { sale of radio and electric } \\
\text { appliances }\end{array}$ & 98.8 & 98.8 & 98.8 & 98.8 & 98.8 \\
\hline $\begin{array}{l}\text { specialized markets } \\
\text { for the sale of building } \\
\text { materials }\end{array}$ & 80.4 & 80.0 & 79.4 & 78.1 & 78.3 \\
\hline agricultural markets & 59.2 & 57.9 & 60.6 & 60.6 & 58.1 \\
\hline $\begin{array}{l}\text { agricultural and cooperative } \\
\text { markets }\end{array}$ & 58.7 & 62.0 & 63.3 & 66.0 & 68.6 \\
\hline $\begin{array}{lll}\text { specialized } & \text { and } \\
\text { markets } & & \end{array}$ & 68.6 & 66.6 & 64.7 & 65.7 & 64.7 \\
\hline
\end{tabular}

We believe that it is necessary for the subjects of the Russian Federation to establish the right to fix a minimum part of the sale of their products to small agricultural producers. This addition is recommended to be included in the Federal Law «On the Basics of State Regulation of Trade Activities in the Russian Federation». The possibility of creating a mechanism for wholesale food markets, which have high demand in many countries, is also financially beneficial. The creation of wholesale food markets with agricultural products is possible with a special decision of state bodies, which will provide trading platforms with transport infrastructure that implements the possibility of using markets to a large number of small entrepreneurs. Note that the trade development strategy developed in 2019 in Russia until 2025 for the first time introduced the concept of wholesale food markets.

The development of online trade in raw materials and food products produced in rural areas is seen as relevant in the modern period. For the implementation and functioning of these sales, it is necessary to introduce a digital platform for the agro-industrial complex in each constituent entity of the Russian Federation without exception, as this provides an 
opportunity to connect agricultural producers with consumers without the participation of intermediaries. Note that at the moment the volume of retail Internet trade in food is minimal.

- Rural development. The development of rural areas does not appear without the development of entrepreneurship. The perspective aimed at modernization and digitalization of production can lead to a reduction in jobs and a decrease in demand for the territories of the agro-industrial complex [14]. The state is faced with the task of effectively using these promising areas, among which priority will be given to supporting the development of nonagricultural activities. For example, transportation of agricultural raw materials, products, etc. The solution to this problem is seen in the following aspects: firstly, through the involvement of the banking unit in the volume of work to finance the main agricultural industries; second, through the systematic development of small businesses in rural areas through the expansion of work tools; thirdly, reimbursement of transport costs to organizations and entrepreneurs engaged in trade activities in remote and small rural areas; fourth, reducing the tax burden; Fifth, through the provision of opportunities and the participation of grants for the formation of non-agricultural businesses

- Rural housing construction. Today, housing construction continues to be one of the most basic areas of development of the modern village. The existing housing construction program does not develop without preferential lending. Young, large and poor families cannot participate in the above-mentioned program because they have a rather low capacity to pay [15]. The study of this problem can be widely argued that the first necessity is to subsidize the initial contribution for housing at the expense of the budget of a certain region. We believe that the introduction of a preferential rate within 5 percent would solve the existing problem. However, the problem of insufficient funds in local budgets for construction, major repairs, reconstruction and the production of design and estimate documents arises from the solution to this problem. In this regard, we believe that it is necessary to provide for «Integration of rural development» within the framework of the state program, which will allow providing subsidies from the federal budget to the budgets of the constituent entities of the Russian Federation.

\section{Conclusions}

Law enforcement as a complex legal tool occupies a leading place in state agrarian policy, is carried out as part of the adoption of power decisions by state and municipal bodies aimed at specific participants in agrarian legal relations.

Having conducted a study of the above aspects, we believe that state support for the agrarian complex of the Russian Federation should keep a focus on the development of the institutional environment and increase the innovative and investment side of agriculture, which can lead to a large increase in production volumes, increase its quality and competitiveness in the market, including ensuring food security of the country.

The positive result of the modern development of the Russian agro-industrial complex is associated with significant achievements in agricultural production. To date, state policy mainly focuses on increasing production volumes and ensuring food security, ensuring food independence from other countries, accelerating import substitution and increasing competitiveness in the domestic and international markets of Russian products produced in rural areas.

The high-quality development of the national legal system and the formation of effective mechanisms to guarantee human and civil rights and freedoms can be carried out only in the context of the consolidation of the resources and capabilities of progressive public structures and the State apparatus. The organizational and legal model of private-state partnership, which is based on mutually beneficial cooperation and trust, acceptable use of legal means can be applied to the national sphere of agriculture and the agro-industrial complex. Taking 
into account the territorial character, the natural and climatic resources of our country, as well as the organizational, legal and technological capabilities, it is possible to assert the presence of promising and relevant characteristics of the concept of agricultural development.

We believe that the studied concept of legal policy, formed in Russian legal science, will improve and establish the main parameters of state agrarian policy.

\section{References}

1. Anisimov and Popova, A. Anisimov, O. Popova, Environm. Policy Law 47, 139-147 (2017)

2. Z.F. Safin, A.Sh. Khabibullina, Law State Theory Practice 12, 65-68 (2014)

3. A.Yu Briukhanov, A.V. Trifanov, A.V. Spesivtsev, I.A. Subbotin, Proceedings of the 19th International Conference on Soft Computing and Measurements SCM, 164-166 (2016)

4. G.M. Lappo, V.Ya. Lyubovnyi, Regional Research of Russia 1, 133-140 (2011)

5. The procedure of substantiation of selection of the energy-efficient design solutions for residential buildings, International Journal of Applied Engineering Research 8, 19263$19276(2015)$

6. E. Khaiturina, S. Kreneva, T. Bakhtina et al., International Multidisciplinary Scientific GeoConference Surveying Geology and Mining Ecology Management, SGEM 18(5.3), 767-774 (2018)

7. Z. Lerman, D. Sedik, RThe Oxford Handbook of the Russian Economy (Oxford University Press, New York, 2013)

8. V. Oliinyk, Journal of Advanced Research in Law and Economics 8(6).28, 1875-1883 (2017)

9. N. Stupak, Environ. Sci. Pol. 68, 10-19 (2017)

10. E. Nikolaeva, Procedia - Social and Behavioral Sciences 238, 364-373 (2018)

11. D.A. Kurakin, O. Visser, Post-Communist Econ. 29(2), 158-181 (2017)

12. B. Kuns, O. Visser, A. Wästfeld, J. Rural. Stud. 45, 199-217 (2016)

13. A. Wolz, S. Golovina, J. Nilsson, S. Hess, Outlook on Agriculture 45, 111-116 (2016)

14. A.F. Shorikov, V.A. Babenko, Economy of Region 1, 196-202 (2014)

15. A.S. Abdulkadyrov, I.V. Ryzhov, A.I. Strokov, Yu.V. Kamzolov, Izvestiya Vysshikh Uchebnykh Zavedenii, Seriya Teknologiya Tekstil'noi Promyshlennosti 371(5), 18-27 (2017) 